\title{
ISOLATION AND PARTIAL PURIFICATION OF $\beta$-GALACTOSIDASES FROM COTYLEDONS OF TWO COWPEA CULTIVARS ${ }^{1}$
}

\author{
JOAQUIM ENÉAS-FILHO ${ }^{2}$, GISLAINY KARLA DA COSTA BARBOSA ${ }^{3}$, FABRÍCIO \\ BONFIM SUDÉRIO ${ }^{4}$, JOSÉ TARQUÍNIO PRISCO ${ }^{5}$ AND ENÉAS GOMES-FILHO ${ }^{6}$
}

Laboratório de Fisiologia Vegetal, Departamento de Bioquímica e Biologia Molecular, Centro de Ciências, Universidade Federal do Ceará, CP 6039, Fortaleza, CE, 60455-900, Brazil.

\begin{abstract}
Three isoforms of $\beta$-galactosidases were isolated and partially purified from the cotyledons of quiescent seeds of Vita 3 and Vita 5 cowpea [Vigna unguiculata (L.) Walp.] cultivars differing in water and salt stress tolerance. The purification procedure consisted of ammonium sulfate fractionation, acid precipitation, ion exchange chromatography through DEAE-sephadex and affinity chromatography through Lactosyl-sepharose columns. The three isoforms isolated from the two cultivars showed the same chromatographic patterns, same optimum of temperature for enzyme activity assay $\left(60^{\circ} \mathrm{C}\right)$, identical thermal stability up to $50^{\circ} \mathrm{C}$, and similar pH optima (3-4). However, they differed from each other in sensitivity towards metal ions and certain chemical agents presents in the assay medium. The results have shown that the observed differences in $\beta$-galactosidases from the cotyledons of quiescent seeds were not sufficient to relate them to stress tolerance.
\end{abstract}

ADDITIONAL INDEX TERMS: cotyledons, isozymes, Vigna unguiculata, Vita 3 and Vita 5 cultivars, salt tolerance.

\section{ISOLAMENTO E PURIFICAÇÃO PARCIAL DE $\beta$-GALACTOSIDASES DE COTILÉDONES DE DOIS CULTIVARES DE FEIJÃO-DE-CORDA}

RESUMO - Três isoformas da enzima $\beta$-galactosidase foram isoladas e purificadas parcialmente a partir de cotilédones de sementes quiescentes dos cultivares Vita 3 e Vita 5 de feijão-de-corda [Vigna unguiculata (L.) Walp.], os quais diferem em tolerância aos estresses hídrico e salino. O processo de purificação consistiu de fracionamento com sulfato de amônio, precipitação ácida, seguida pela associação de cromatografia de troca iônica em coluna de DEAE-Sephadex com cromatografia de afinidade em coluna de Lactosyl-Sepharose. As três isoformas isoladas dos dois cultivares mostraram os mesmos padrões cromatográficos, mesma temperatura ótima de ensaio para atividade enzimática $\left(60^{\circ} \mathrm{C}\right)$, idêntica estabilidade térmica até $50^{\circ} \mathrm{C}$ e apresentaram ótimos de $\mathrm{pH}$ semelhantes (3-4). Entretanto, diferiram umas das outras em suas sensibilidades a íons metálicos e a certos agentes químicos presentes no meio de reação. Os resultados mostraram que as diferenças observadas nas $\beta$-galactosidases de cotilédones de sementes quiescentes foram insuficientes para correlacioná-las com a tolerância ao estresse.

1. Received: 15/8/2001 - Accepted: 20/11/2001

2. Biólogo, M.S., Dr. 3ème Cycle, Prof. Adjunto IV, Pesq./CNPq - Corresponding author. e-mail: joaquime@ufc.br

3. Bióloga, Bolsista do CNPq.

4. Biólogo, Bolsista da CAPES.

5. Eng. Agron., M.S., Ph.D., Prof. Emérito, Pesq./CNPq.

6. Eng. Quim., M.S., Dr., Prof. Adjunto IV, Pesq./CNPq. 
TERMOS ADICIONAIS PARA INDEXAÇÃO: cotilédones, isoenzimas, Vigna unguiculata, cultivares Vita 3 e Vita 5, tolerância à sais.

\section{INTRODUCTION}

$\beta$-galactosidases (EC 3.2.1.23) are hydrolytic enzymes occurring in different organs of several plant species. It has been suggested that they are responsible for the removal of galactose from cytosolic or membrane bound glycoproteins, and from cell wall pectins and hemicelluloses (Edwards et al., 1988; Veau et al., 1993; Kim et al., 1999). In spite of much effort their physiological role is still not well understood (Kundu et al., 1990; Konno and Katoh, 1992; Buckeridge and Reid, 1994; Tiné et al., 2000). These enzymes have been associated with depletion of oligo- and polysaccharides during seed reserve mobilization (Enéas-Filho et al., 1995; Alcântara et al., 1999; Li et al., 2001) as well as during the process of cell wall loosening for cell elongation (Dopico et al., 1990; Konno and Tsumuki, 1993; Stolle-Smits et al., 1999). Furthermore, they have been related to fruit ripening processes (Kitagawa et al., 1995; Prabha and Bhagyalakshmi, 1998; Barnavon et al., 2000). In order to study their physiological and biochemical role it is fundamental to identify the possible isoforms existing in different plant organs, purify, and characterize them as well as determine their exact location within the tissue or within the cell.

It is known that there are several $\beta$ galactosidase isozymes in the quiescent seeds of different plant species (Giannakouros et al., 1991; Ali et al., 1995; Enéas-Filho et al., 2000) but it is not known if these isozymes are species specific or if they vary among cultivars of the same species. Knowing that cowpea cultivars respond differently to environmental stresses during germination and seedling establishment (Melo et al., 1994; GomesFilho et al., 1996) and that $\beta$-galactosidases are involved in cell elongation (Dopico et al., 1990; Konno and Tsumuki, 1993; Stolle-Smits et al., 1999), it was hypothesized that cultivars differing in stress tolerance (Melo et al., 1994; Gomes-Filho et al., 1996) could have different forms of $\beta$ galactosidases. Therefore, the present paper describes the isolation and partial purification of $\beta$ galactosidases from cotyledon of two cultivars differing in stress tolerance as well as the determination of some of their physical and chemical properties aiming to relate these enzymes to stress tolerance.

\section{MATERIAL AND METHODS}

\section{Materials}

Seeds of Vita 3 (water stress tolerant) and Vita 5 (water stress sensitive) cultivars of Cowpea [Vigna unguiculata (L.) Walp.], were a gift from the Centro Nacional de Pesquisa do Arroz e Feijão (CNPAF/Embrapa), Goiânia, Goiás, Brazil. All seeds were stored in sealed glass bottles containing silica gel and kept at approximately $10^{\circ} \mathrm{C}$ until used in the experiments. $p$-Nitrophenyl $\beta$-Dgalactopyranoside, BSA $2 x$ crystalline, DEAESephadex A-50 and Lactosyl-Sepharose were purchased from Sigma. All other reagents were of analytical grade.

\section{Preparation of enzyme extract}

$\beta$-galactosidase extraction was performed according to Corchete and Guerra (1987) with small modifications. Cotyledons of quiescent seeds were homogenized in cold $25 \mathrm{mM}$ citrate $/ 50 \mathrm{mM}$ phosphate buffer (McIlvaine, 1921), $\mathrm{pH}$ 5.5, for $1 \mathrm{~h}$. The proportion of tissue to grinding medium was $1: 10(\mathrm{~m} / \mathrm{v})$. All procedures were performed at $4^{\circ} \mathrm{C}$ unless stated otherwise. The suspension was filtered through a nylon net and centrifuged at $10,000 \times \mathrm{g}$ for $30 \mathrm{~min}$. The supernatant (crude extract) was precipitated with ammonium sulfate in the range of $20-60 \%$ saturation. After centrifugation, the precipitate was resuspended in McIlvaine buffer, $\mathrm{pH} 5.5$ and then lowered to $\mathrm{pH}$ 3.5 with $1 \mathrm{M}$ citric acid. The resulting precipitate was discarded after centrifugation at $10,000 \mathrm{x} g$ for $30 \mathrm{~min}$ and the $\mathrm{pH}$ of the supernatant adjusted to 
5.5 with $0.8 \mathrm{M} \mathrm{Na}_{2} \mathrm{HPO}_{4}$, which was then dialyzed against deionized distilled water at $8^{\circ} \mathrm{C}$ for $24 \mathrm{~h}$, and lyophilized $\left(\mathrm{F}_{20-60}\right)$ for further use.

\section{Protein determination}

Protein was determined according to Bradford (1976), using BSA as standard.

\section{Enzyme assay}

$\beta$-Galactosidase activity was measured according to Kanfer et al. (1973) as modified by Enéas-Filho et al. (1995). A $3 \mathrm{mM}$ solution of the substrate was prepared by dissolving p-nitrophenyl $\beta$-D-galactopyranoside in McIlvaine buffer, $\mathrm{pH}$ 4.0. A $0.5 \mathrm{~mL}$ aliquot of this solution was added to $0.5 \mathrm{~mL}$ of appropriately diluted enzyme extract, and the mixture was incubated at $37^{\circ} \mathrm{C}$ for 15 $\min$. The reaction was stopped by the addition of $1.5 \mathrm{~mL}$ of $0.1 \mathrm{M} \mathrm{Na}_{2} \mathrm{CO}_{3}$. Enzyme activity was determined by measuring absorbance at $400 \mathrm{~nm}$ $\left(\mathrm{A}_{400}\right)$ and subtracting this value from the absorbance $\left(\mathrm{A}_{400}\right)$ of the blank. Enzyme activity was expressed in units of activity (UA), being one UA defined as a difference in absorbance $\left(\Delta \mathrm{A}_{400}\right)$ of 0.01 .

\section{Ion exchange chromatography}

The lyophilized $\mathrm{F}_{20-60}$ was resuspended in $25 \mathrm{mM}$ Tris/HCl buffer, $\mathrm{pH} 7.2$ and applied on a DEAE-Sephadex A-50 ion-exchange column (1.7 $\mathrm{x} 18 \mathrm{~cm})$ previously equilibrated with the same buffer. The flow rate was adjusted to $31.5 \mathrm{~mL} \cdot \mathrm{h}^{-1}$, and $4.2 \mathrm{~mL}$ fractions were eluted with the equilibrium buffer at $10^{\circ} \mathrm{C}$. The material retained by the column was eluted with a linear $\mathrm{NaCl}$ gradient $(0-1 \mathrm{M})$. Absorbance at $280 \mathrm{~nm}$ (protein) and $\beta$-galactosidase activity were determined in each fraction, and the ones that showed the highest activities (peaks DS-I and DSII) were dialyzed against deionized distilled water for $24 \mathrm{~h}$.

\section{Affinity chromatography}

The peaks DS-I and DS-II were separately concentrated and applied on a LactosylSepharose affinity column (1.6 x 19 cm) equilibrated with diluted 1:4 (v/v) McIlvaine buffer $\mathrm{pH} 4.0$, containing $0.1 \mathrm{mM}$ EDTA and $1.0 \mathrm{mM} 2-$ $\mathrm{ME}$ at $4^{\circ} \mathrm{C}$ (Campillo and Shannon, 1982). The flow rate was adjusted to $36 \mathrm{~mL} \cdot \mathrm{h}^{-1}$, and $4.8 \mathrm{~mL}$ fractions were eluted with the equilibrium buffer. The material retained by the column was eluted with the same buffer containing $100 \mathrm{mM}$ lactose and $0.5 \mathrm{M} \mathrm{NaCl}$. The column eluate was monitored at $280 \mathrm{~nm}$ for protein and assayed for $\beta$ galactosidase activity.

\section{Physical and chemical properties of the $\beta$ - galactosidases}

In order to study the $\mathrm{pH}$-dependent kinetic of the enzyme both the enzyme and the substrate were dissolved in McIlvaine buffer in a $\mathrm{pH}$ range from 2.0 to 6.5 . To determine the optimum temperature of the assay medium for enzyme activity, the reaction mixture was incubated at $30,40,50,60,70$ and $80^{\circ} \mathrm{C}$ for 15 $\mathrm{min}$, and the reaction stopped as described in enzyme assay. Thermal stability was studied taking $0.5 \mathrm{~mL}$ aliquots of the enzyme (dissolved in McIlvaine buffer, $\mathrm{pH} 4.0$ ) and incubating it for $10 \mathrm{~min}$ at temperatures ranging from 30 to $70^{\circ} \mathrm{C}$. After cooling, the treated enzyme samples were assayed for $\beta$-galactosidase activity. The effect of EDTA, galactose, glucose, lactose, tartrate, molybdate and several bivalent cations on enzyme activity were tested by preincubating $0.5 \mathrm{~mL}$ aliquots of the enzyme preparation at $37^{\circ} \mathrm{C}$ for $10 \mathrm{~min}$ in the absence and presence of the effectors, and then assaying the mixture for enzyme activity. The final concentration of all effectors in preincubating and in the assay medium was $4 \mathrm{mM}$, except for molybdate that was $0.1 \mathrm{mM}$ and for galactose, glucose and lactose that were $8 \mathrm{mM}$. 


\section{RESULTS AND DISCUSSION}

\section{$\beta$-galactosidase purification}

Fraction $\mathrm{F}_{20-60}$ from both Vita 3 and Vita 5 cultivars, subjected to ion exchange chromatography (Figures 1A and 1B) was fractionated in two distinct peaks (DS-I and DSII) both displaying $\beta$-galactosidase activity. While DS-I was unbound to the column DS-II was bound and later eluted with $0.7 \mathrm{M} \mathrm{NaCl}$. When DS-I was applied on the Lactosyl-Sepharose affinity column it was further fractionated into $\beta$-gal I and $\beta$-gal II peaks (Figures 1C and 1D). $\beta$-gal I was purified 7.4- and 3.4-fold, whereas $\beta$-gal II was purified 53.5- and 21.5-fold, for Vita 3 and Vita 5 cultivars, respectively (Table 1). When DS-II was applied on Lactosyl-Sepharose column only a single peak ( $\beta$ gal III) emerged after washing the column with $100 \mathrm{mM}$ lactose (Figures $1 \mathrm{E}$ and 1F). This represented 16.2- and 12.4-fold purification for Vita 3 and Vita 5, respectively (Table 1). Thus, using this purification procedure it was observed that there are at least three isoforms of $\beta$ galactosidases in seeds of Vita 3 and Vita 5 cultivars of cowpea. Our results are in agreement with those reported by Enéas-Filho et al. (2000) who showed the presence of three $\beta$-galactosidase isoforms in quiescent seeds of Pitiúba cowpea. The presence of four isoforms of this enzyme were detected in cotyledons from 4 day-old seedlings of Vigna sinensis (Biswas, 1987) and of Vigna radiata (Kundu et al., 1990). However, Dey (1984) working with mature seeds of the latter species detected only one $\beta$-galactosidase. These results suggest that there are differences in numbers of $\beta$ galactosidases among species of the same genus and that the same species could have different isozymes along seed germination and seedling establishment.

\section{Effects of $\mathrm{pH}$ and temperature}

$\beta$-galactosidase activity measured as a function of $\mathrm{pH}$ showed that $\beta$-gal III from Vita 3 cultivar was fully active at $\mathrm{pH} 3.0$ whereas $\beta$-gal I and $\beta$-gal II showed maximal activity at $\mathrm{pH} 3.5$
(Figure 2A). For Vita 5, $\beta$-gal II maximal activity was at $\mathrm{pH} 3.5$ as compared to $\mathrm{pH} 4.0$ for $\beta$-gal I and $\beta$-gal III (Figure 2B). The optimal temperature of the assay medium was $60^{\circ} \mathrm{C}$ for the three $\beta$ galactosidases studied (Figures $2 \mathrm{C}$ and 2D). These values, although slightly different, were similar to the ones obtained for $\beta$-galactosidases isolated from cotyledons of Pitiúba cowpea (Enéas-Filho et al., 2000), from seedlings (Li et al., 2001) and cotyledons (Kundu et al., 1990) of Vigna radiata as well as from seeds and leaves of other plant species (Simos et al., 1989; Sawicka and Kacperska, 1995). The difference in the temperature used in the assay medium $\left(37^{\circ} \mathrm{C}\right)$ and that found in the optimum assay temperature experiment carried out with the partially purified enzyme (Figures 2C and 2D) was also observed by Li et al. (2001).

Enzyme thermal stability of partially purified $\beta$-galactosidase isoforms from cotyledon of Vita 3 and Vita 5 cultivars are shown in Figures $2 \mathrm{E}$ and $2 \mathrm{~F}$, respectively. All isozymes when preincubated at temperatures ranging from $30-50^{\circ} \mathrm{C}$ were heat stable, and inactivated at $70^{\circ} \mathrm{C}$. Similar thermal stability was already reported for $\beta$ galactosidases extracted from cotyledon of Pitiúba cowpea (Enéas-Filho et al., 2000), and for $\beta$ galactosidases extracted from seeds and leaves of other plant species (Simos and Georgatsos, 1988; Konno and Tsumuki, 1993). The results of the optimal assay temperature for the partially purified enzyme have shown that the maximal activity is at $60^{\circ} \mathrm{C}$ (Figures 2C and 2D) while the thermal stability of the enzyme started to decreased above $50^{\circ} \mathrm{C}$ (Figures 2E and 2F). This apparent discrepancy could be interpreted as being due to differences in the microenvironment in which the enzyme was subjected. In the thermal stability experiments the enzyme was not as protected to high temperatures as in the assay medium. In the latter the enzyme molecules form enzymesubstrate complexes that are much more stable (Nelson and Cox, 2000).

The results shown in Figure 2 indicate that although there are slight differences in $\mathrm{pH}$ optima between $\beta$-galactosidase isoforms from cotyledon of quiescent seeds of Vita 3 and Vita 5, they are not sufficient to explain the differences in stress tolerance between these cultivars. 


\section{Effects of bivalent cations and other efectors}

With the exception of $\mathrm{Ca}^{2+}$, the bivalent cations tested had inhibitory effects on the activity of $\beta$-galactosidase isoforms (Table 2) being $\mathrm{Hg}^{2+}$ and $\mathrm{Cu}^{2+}$ the ions that caused the strongest inhibition of the three isoforms studied. $\beta$-gal I extracted from both cultivars practically were not affected by $\mathrm{Mn}^{2+}$ nor by $\mathrm{Mg}^{2+}$ but these ions inhibited both $\beta$-gal II and $\beta$-gal III. The inhibition of isoforms activity due to $\mathrm{Zn}^{2+}$, tartrate, molybdate and glucose varied according to the cultivar. $\mathrm{Co}^{2+}$ was a strong inhibitor of $\beta$-gal II and $\beta$-gal III but a slight inhibitor of $\beta$-gal I. EDTA and lactose moderately inhibited $\beta$ galactosidase activities of isoforms from both cowpea cultivars. As expected galactose, a product of the action of $\beta$-galactosidases, was a strong inhibitor of all isoforms of $\beta$-galactosidases extracted from cotyledon of the cowpea cultivars studied. Similar results were found for the multiple forms of $\beta$ galactosidases from cotyledon of Pitiúba cowpea (Enéas-Filho et al., 2000) and for $\beta$-galactosidases isolated from other plant sources (Kundu et al., 1990; Ogawa et al., 1990; Li et al., 2001).

TABLE 1 - Purification of $\beta$-galactosidases from the cotyledons of quiescent seeds of two Vigna unguiculata (L.) Walp. cultivars. Data represent the average of three experiments.

\begin{tabular}{|c|c|c|c|c|c|c|c|c|}
\hline \multirow[t]{2}{*}{$\begin{array}{c}\text { Step of } \\
\text { Purification* }\end{array}$} & \multicolumn{2}{|c|}{$\begin{array}{l}\text { Total Activity } \\
\text { (UA.min }{ }^{-1} \text { ) }\end{array}$} & \multicolumn{2}{|c|}{$\begin{array}{l}\text { Total Protein } \\
\qquad(\mathrm{mg})\end{array}$} & \multicolumn{2}{|c|}{$\begin{array}{l}\text { Specific Activity } \\
\left(\mathrm{UA} \cdot \mathrm{mgP}^{-1} \cdot \mathrm{min}^{-1}\right)\end{array}$} & \multicolumn{2}{|c|}{$\begin{array}{c}\text { Factor of } \\
\text { Purification (fold) }\end{array}$} \\
\hline & Vita 3 & Vita 5 & Vita 3 & Vita 5 & Vita & 3 Vita 5 & Vita & 3 Vita 5 \\
\hline Crude Extract & 44,704 & 36,719 & 1,109 & 1,126 & 40.3 & 32.6 & 1 & 1 \\
\hline $\mathrm{F}_{20-60}$ & 28,173 & 22,766 & 158 & 127 & 178 & 179 & 4.4 & 5.5 \\
\hline \multicolumn{9}{|c|}{ DEAE-Sephadex chromatography } \\
\hline DS-I & 13,152 & 10,086 & 15 & 21 & 877 & 480 & 21.8 & 14.7 \\
\hline DS-II & 10,611 & 7,086 & 127 & 63 & 84 & 112 & 2.1 & 3.4 \\
\hline \multicolumn{9}{|c|}{ Lactosyl-Sepharose affinity chromatography } \\
\hline$\beta$-gal I & 2,085 & 3,322 & 7 & 30 & 298 & 111 & 7.4 & 3.4 \\
\hline$\beta$-gal II & 4,311 & 2,106 & 2 & 3 & 2,156 & 702 & 53.5 & 21.5 \\
\hline$\beta$-gal III & 5,217 & 1,212 & 8 & 3 & 652 & 404 & 16.2 & 12.4 \\
\hline
\end{tabular}

R. Bras. Fisiol. Veg., 13(3):251-261, 2001 
Vita 3
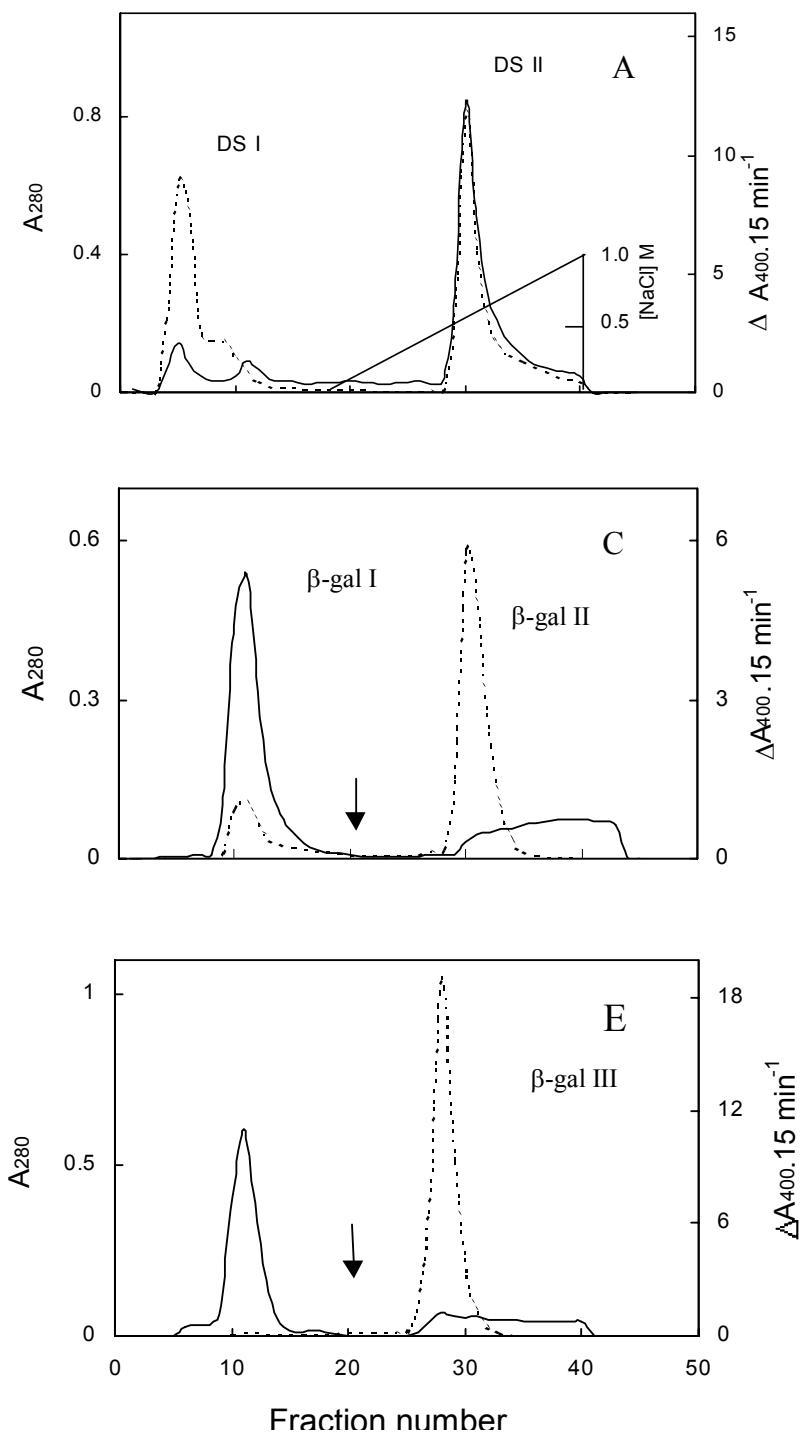

Vita 5
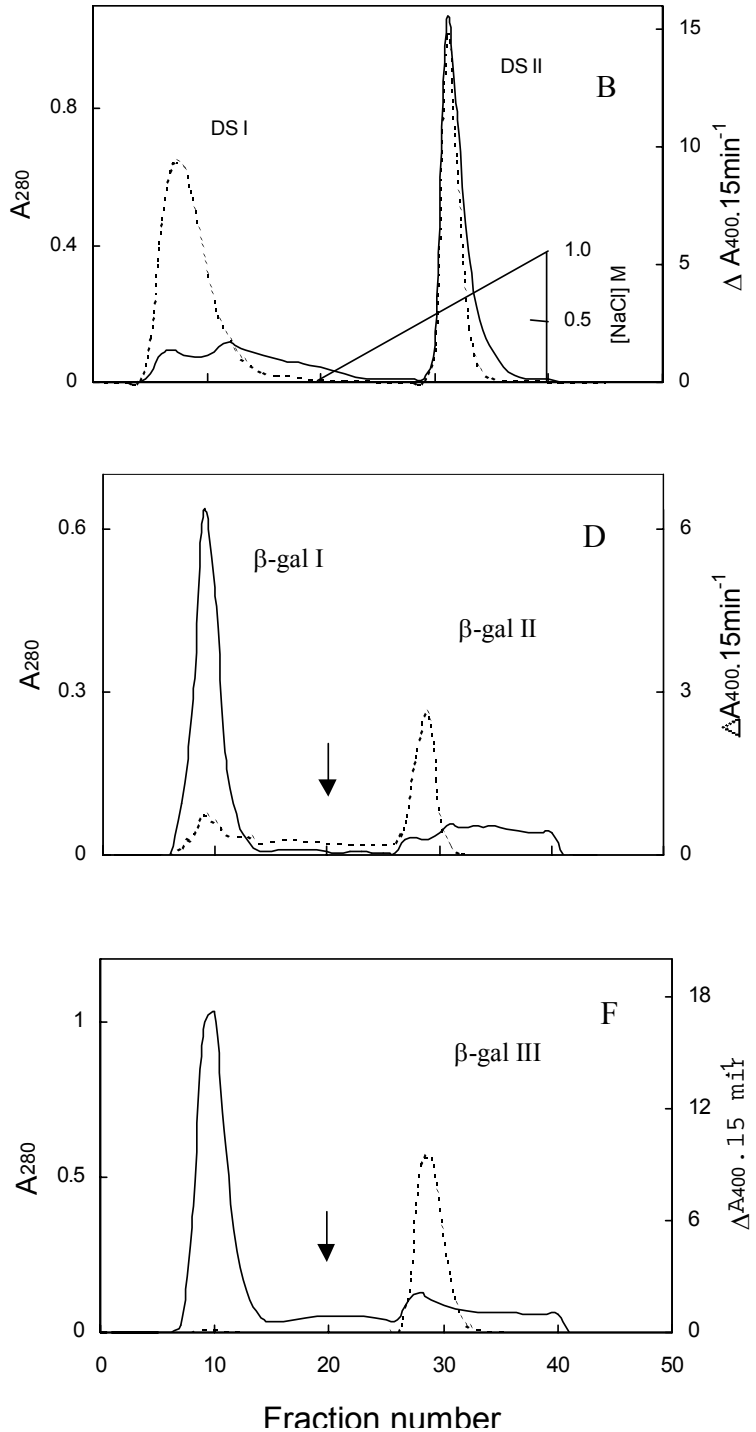

FIGURE 1 - Purification of $\beta$-galactosidases extracted from the cotyledons of Vita 3 and Vita 5 cowpea [Vigna unguiculata (L.) Walp.] quiescent seeds. A and B - DEAE-Sephadex A-50 chromatography of $\beta$ galactosidase rich fraction $\left(F_{20-60}\right)$. $\mathbf{C}$ and $\mathbf{D}$ - Lactosyl-Sepharose affinity chromatography of $\beta$ galactosidase rich peak (DS-I). $\mathbf{E}$ and $\mathbf{F}$ - Lactosyl-Sepharose affinity chromatography of $\beta$-galactosidase rich peak (DS-II). Protein $\left(\mathrm{A}_{280},-\right)$ and $\beta$-galactosidase activity $\left(\Delta \mathrm{A}_{400} \times 15 \mathrm{~min}^{-1}\right.$, ---). The arrows represent the start of the addition of the elution buffer containing $100 \mathrm{mM}$ lactose and $0.5 \mathrm{M} \mathrm{NaCl}$ as described in Material and Methods. 
Vita 3
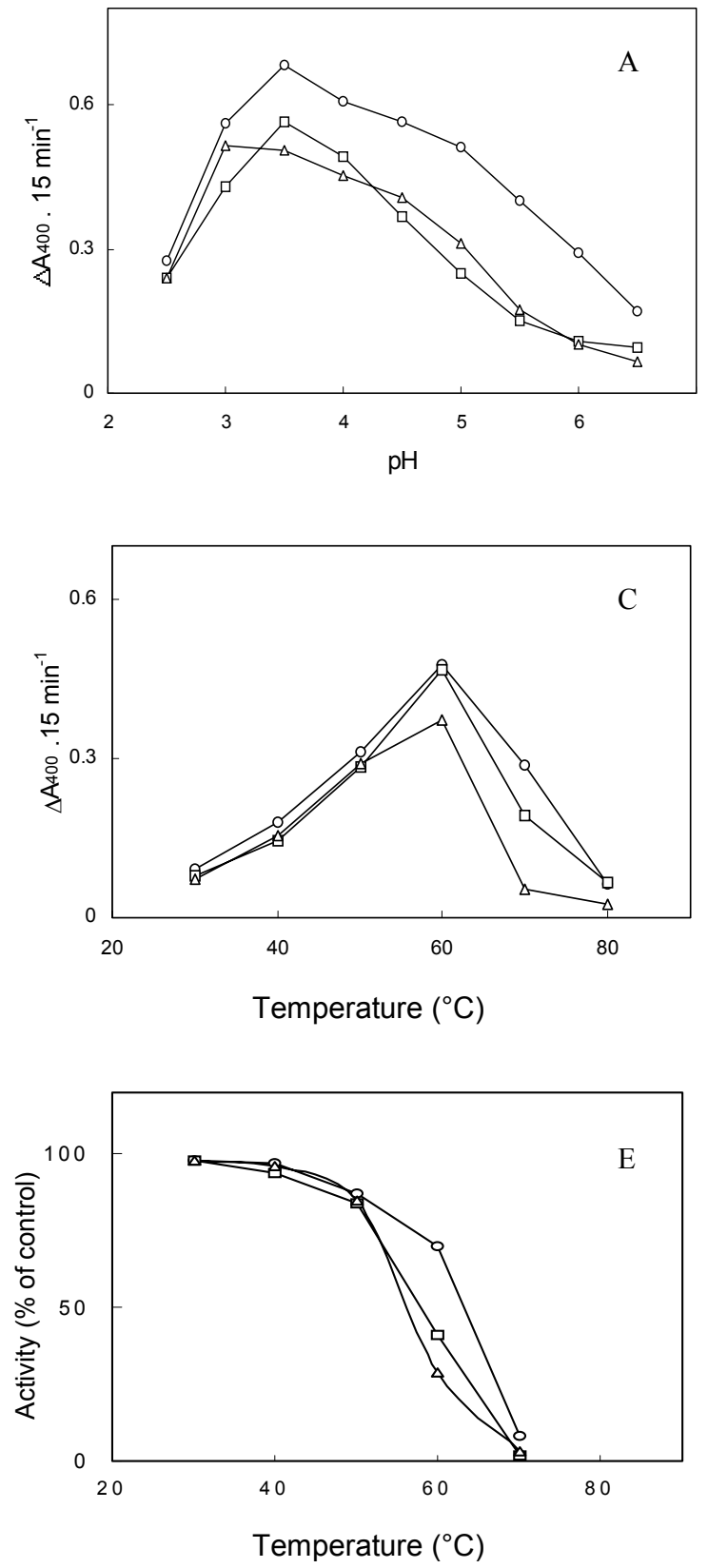

Vita 5
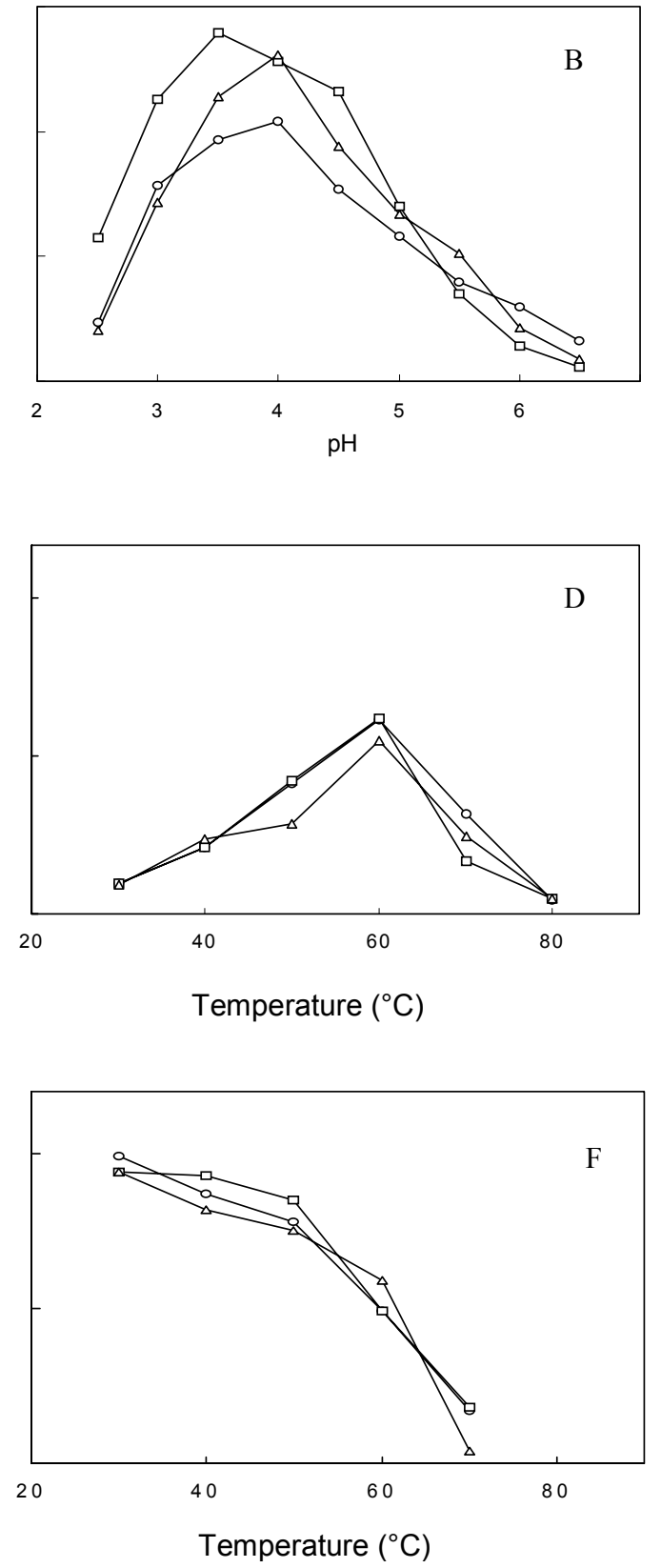

FIGURE 2 - Enzyme activity as a function of the assay medium $\mathrm{pH}(\mathbf{A}$ and $\mathbf{B})$, temperature (C and $\mathbf{D})$ and enzyme thermal stability ( $\mathbf{E}$ and $\mathbf{F}$ ) of partially purified $\beta$-galactosidases extracted from the cotyledons of Vita 3 and Vita 5 cowpea [Vigna unguiculata (L.) Walp.] quiescent seeds. $\beta$-gal I (o), $\beta$-gal II ( $\square$ ) and $\beta$ gal III $(\Delta)$. Values represent the mean of three different experiments with three replicates each. 
TABLE 2 - Effect of bivalent cations and other effectors on the activity of purified $\beta$-galactosidases from the cotyledons of quiescent seeds of two Vigna unguiculata (L.) Walp. cultivars. The values are expressed in percentage of the control (enzyme assayed without the addition of effectors) and represent the mean \pm standard deviation of three different experiments with three replicates each.

Final

Addition Concentration
Activity (\% of control)

\begin{tabular}{|c|c|c|c|c|c|c|c|}
\hline & $(\mathrm{mM})$ & $\beta$-gal I & $\beta$-gal II & $\beta$-gal III & $\beta$-gal I & $\beta$-gal II & $\beta$-gal III \\
\hline $\mathrm{MnCl}_{2}$ & 4 & $94 \pm 5.5$ & $59 \pm 8.8$ & $53 \pm 8.2$ & $91 \pm 1.0$ & $55 \pm 4.5$ & $32 \pm 1.0$ \\
\hline $\mathrm{MgCl}_{2}$ & 4 & $90 \pm 7.8$ & $47 \pm 1.0$ & $48 \pm 1.0$ & $86 \pm 1.7$ & $41 \pm 3.5$ & $46 \pm 6.1$ \\
\hline $\mathrm{CaCl}_{2}$ & 4 & $111 \pm 14.7$ & $115 \pm 6.2$ & $96 \pm 10.0$ & $102 \pm 4.5$ & $112 \pm 3.0$ & $103 \pm 3.4$ \\
\hline $\mathrm{ZnCl}_{2}$ & 4 & $73 \pm 2.3$ & $76 \pm 5.1$ & $47 \pm 7.5$ & $78 \pm 9.0$ & $4 \pm 1.1$ & $6 \pm 2.5$ \\
\hline $\mathrm{CoCl}_{2}$ & 4 & $73 \pm 4.5$ & $5 \pm 4.5$ & $10 \pm 4.9$ & $69 \pm 8.7$ & $7 \pm 4.0$ & $9 \pm 0.5$ \\
\hline $\mathrm{CuCl}_{2}$ & 4 & $1 \pm 1.0$ & $3 \pm 2.1$ & $1 \pm 1.5$ & $0 \pm 0$ & $1 \pm 1.7$ & $17 \pm 4.0$ \\
\hline $\mathrm{HgCl}_{2}$ & 4 & $0 \pm 0.6$ & $3 \pm 2.3$ & $2 \pm 2.5$ & $0 \pm 0.5$ & $1 \pm 1.7$ & $0 \pm 0$ \\
\hline EDTA & 4 & $82 \pm 3.8$ & $75 \pm 3.0$ & $91 \pm 1.5$ & $84 \pm 3.0$ & $90 \pm 7.2$ & $82 \pm 4.3$ \\
\hline Tartrate & 4 & $66 \pm 9.3$ & $57 \pm 3.2$ & $46 \pm 5.3$ & $6 \pm 6.0$ & $0 \pm 0$ & $0 \pm 0$ \\
\hline Molybdate & 0.1 & $65 \pm 6.2$ & $1 \pm 0.6$ & $79 \pm 8.0$ & $25 \pm 2.3$ & $73 \pm 2.8$ & $35 \pm 3.0$ \\
\hline Galactose & 8 & $37 \pm 6.1$ & $15 \pm 2.0$ & $34 \pm 2.9$ & $39 \pm 1.5$ & $33 \pm 3.2$ & $31 \pm 6.0$ \\
\hline Glucose & 8 & $82 \pm 1.0$ & $83 \pm 7.1$ & $83 \pm 4.3$ & $84 \pm 8.5$ & $47 \pm 0.5$ & $39 \pm 1.7$ \\
\hline Lactose & 8 & $76 \pm 6.5$ & $75 \pm 10.2$ & $64 \pm 0.6$ & $89 \pm 8.0$ & $81 \pm 4.0$ & $71 \pm 6.0$ \\
\hline
\end{tabular}


These results indicate that the three $\beta$ galactosidases isoforms in spite of having the same optimum assay temperature, identical thermal stability, and similar optimum $\mathrm{pH}$ responded differently when exposed to the various effectors presents in the assay medium, suggesting that they may belong to a same general family of $\beta$ galactosidases that were stored in the seed during their development as it was demonstrated during tomato fruit development (Smith and Gross, 2000). Even though, the response of the three isozymes to $\mathrm{Zn}^{2+}$, tartrate, molybdate and glucose had varied between the two cultivars, our data is not sufficient to infer that these differences are related to stress tolerance. At best, it could be speculated that these isoforms could have different metabolic roles during germination and seedling establishment. Therefore, the role of $\beta$-galactosidases in stress tolerance continues to be speculative and deserves more investigation.

\section{ACKNOWLEDGEMENTS}

To the Conselho Nacional de Desenvolvimento Científico e Tecnológico (CNPq), the Financiadora de Estudos e Projetos (FINEP) and the Fundação Cearense de Apoio ao Desenvolvimento Científico e Tecnológico (FUNCAP) for financial support.

\section{REFERENCES}

ALCÂNTARA, P. H. N., DIETRICH, S. M. C. \& BUCKERIDGE, M. S. Xyloglucan mobilisation and purification of a (XLLG/XLXG) specific $\beta$-Galactosidase from cotyledons of Copaifera langsdorffii. Plant Physiology and Biochemistry, 37: 653-663, 1999.

ALI, Z. M., ARMUGAM, S. \& LAZAN, H. $\beta$ Galactosidase and its significance in ripening mango fruit. Phytochemistry, 38: 1109-1114, 1995.
BARNAVON, L., DOCO, T., TERRIER, N., AGCORGES, A., ROMICU, C. \& PELLERIN, P. Analysis of cell wall neutral sugar composition, $\beta$-galactosidase activity and a related cDNA clone throughout the development of Vitis vinifera grape berries. Plant Physiology and Biochemistry, 38: 289300, 2000.

BISWAS, T. K. Characterization of $\beta$-galactosidases from germinating seeds of Vigna sinensis. Phytochemistry, 26: 359-364, 1987.

BRADFORD, M. M. A rapid and sensitive method for the quantitation of microgram quantities of protein utilizing the principle of protein-dye binding. Analytical Biochemistry, 72: 248254, 1976.

BUCKERIDGE, M. S. \& REID, J. S. G. Purification and properties of a novel $\beta$-galactosidase or exo(1-4)- $\beta$-D-galactanase from the cotyledons of germinated Lupinus angustifolius L. seeds. Planta, 192: 502-511, 1994.

CAMPILLO, E. D. \& SHANNON, L. M. An $\alpha-$ galactosidase with hemagglutinin properties from soybean seeds. Plant Physiology, 69: 628-631, 1982.

CORCHETE, M. P. \& GUERRA, H. $\alpha$ - and $\beta$ galactosidase activities during germination of lentil seeds. Plant Physiology and Biochemistry, 25: 105-109, 1987.

DEY, P. M. Occurrence of glycoprotein glycosidases in mature seeds of mung bean (Vigna radiata). Phytochemistry, 23: 257260, 1984.

DOPICO, B., NICOLÁS, G. \& LABRADOR, E. Characterization of a cell wall $\beta$-galactosidase of Cicer arietinum epicotyls involved in cell wall autolysis. Physiologia Plantarum, 80: 629-635, 1990. 
EDWARDS, M., BOWMAN, Y. J. L., DEA, I. C. M. \& REID, J. S. G. A $\beta$-galactosidase from nasturtium (Tropaeolum majus L.) cotyledons. The Journal of Biological Chemistry, 263: 4333-4337, 1988.

ENÉAS-FILHO, J., OLIVEIRA-NETO, O. B., PRISCO, J. T., GOMES-FILHO, E. \& NOGUEIRA, C. M. Effects of salinity in vivo and in vitro on cotyledonary galactosidases from Vigna unguiculata (L.) Walp. during seed germination and seedling establishment. Revista Brasileira de Fisiologia Vegetal, 7: 135-142, 1995.

ENÉAS-FILHO, J., SUDÉRIO, F. B., GOMESFILHO, E. \& PRISCO, J. T. Multiple forms of cotyledonary $\beta$-galactosidases from Vigna unguiculata quiescent seeds. Revista Brasileira de Botânica, 23: 69-76, 2000.

GIANNAKOUROS, T., KARAGIORGOS, A. \& SIMOS, G. Expression of $\beta$-galactosidase multiple forms during barley (Hordeum vulgare) seed germination. Separation and characterization of enzyme isoforms. Physiologia Plantarum, 82: 413-418, 1991.

GOMES-FILHO, E., ENÉAS-FILHO, J. \& PRISCO, J. T. Effects of osmotic stress on growth and ribonuclease activity in Vigna unguiculata (L.) Walp. seedlings differing in stress tolerance. Revista Brasileira de Fisiologia Vegetal, 8: 51-57, 1996.

KANFER, J. N., PETROVICH, R. \& MUMFORD, R. A. Purification of $\alpha$ - and $\beta$-galactosidases by affinity chromatography.

Biochemistry, 55: 301-305, 1973.

KIM, J., SOLOMOS, T. \& GROSS, K. C. Changes in cell wall galactosyl and soluble galactose content in tomato fruit stored in low oxygen atmospheres. Postharvest Biology and Technology, 17: 33-34, 1999.
KITAGAWA, Y., KANAYAMA, Y. \& YAMAKI, $S$. Isolation of $\beta$-galactosidase fractions from japanese pear: Activity against native cell wall polysaccharides. Physiologia Plantarum, 93: 545-550, 1995.

KONNO, H., \& KATOH, K. An extracellular $\beta-$ galactosidase secreted from cell suspension cultures of carrot. Its purification and involvement in cell wall-polysaccharide hydrolysis. Physiologia Plantarum, 85: 507514, 1992.

KONNO, H. \& TSUMUKI, H. Purification of a $\beta$ galactosidase from rice shoots and its involvement in hydrolysis of the natural substrate in cell walls. Physiologia Plantarum, 89: 40-47, 1993.

KUNDU, R. K., DE-KUNDU, P. \& BANERJEE, A. C. Multiple forms $\beta$-galactosidase from the germinating seeds of Vigna radiata. Phytochemistry, 29: 2079-2082, 1990.

LI, S-C., HAN, J-W., CHEN, K-C. \& CHEN, C-S. Purification and characterization of isoforms of $\beta$-galactosidases in mung bean seedlings. Phytochemistry, 57: 349-359, 2001.

MCILVAINE, T. C. A buffer solution for colorimetric comparison. The Journal Biological Chemistry, 49: 185-186, 1921.

MELO, D. F., JOLIVET, Y., FAÇANHA, A. R., GOMES-FILHO, E., LIMA, M. S. \& DIZENGREMEL, P. Effect of salt stress on mitochondrial energy metabolism of Vigna unguiculata ciltivars differing in $\mathrm{NaCl}$ tolerance. Plant Physiology and Biochemistry, 32: 405-412, 1994.

NELSON, D. L. \& COX, M. M. Lehninger Principles of Biochemistry. New York, Worth Publishers, 2000. 243-292. 
OGAWA, H., FUKUMOTO, H., YANO, T., YAMAMOTO, K. \& TOCHIKURA, T. Purification and characterization of $\beta$ galactosidase from kiwifruit. Nippon Shokuhin Kogyo Gakkaishi, 37: 298-305, 1990.

PRABHA, T. N. \& BHAGYALAKSHMI, N. Carbohydrate metabolism in ripening banana fruit. Phytochemistry, 48: 915-919, 1998.

SAWICKA, T. \& KACPERSKA, A. Soluble and cell wall-associated $\beta$-galactosidases from cold-grown rape (Brassica napus L., var. oleifera L.) leaves. Journal Plant Physiology, 145: 357-362, 1995.

SIMOS, G. \& GEORGATSOS, J. G. Lactosehydrolyzing $\beta$-glycosidases of barley meal. Biochimica et Biophysica Acta, 967: 17-24, 1988.

SIMOS, G., GIANNAKOUROS, T. \& GEORGATSOS, J. G. Plant $\beta$-galactosidases: purification by affinity chromatography and properties. Phytochemistry, 28: 2587-2592, 1989.
SMITH, D. L. \& GROSS, K.C. A family of at seven $\beta$-galactosidase gene is expressed during tomato fruit development. Plant Physiology, 123: 1173-1183, 2000.

STOLLE-SMITS, T., BEEKHUIZEN, J. G., KOK, M. T. C., PIJNENBURG, M., RECOURT, K., DERKSEN, J. \& VORAGEN, A. G. J. Changes in cell wall polysaccharides of green bean pods during development. Plant Physiology, 121: 363-372, 1999.

TINÉ, M. A. S., CORTElazzO, A. L. \& BUCKERIDGE, M. S. Xyloglucan mobilisation in cotyledons of developing plantlets of Hymenaea courbaril L. (Leguminosae-Caesalpinoideae). Plant Science, 154: 117:126, 2000.

VEAU, E. J. I., GROSS, K. C., HUBER, D. .J. \& WATADA, A. E. Degradation and solubilization of pectin by $\beta$-galactosidases purified from avocado mesocarp. Physiologia Plantarum, 87: 279-285, 1993. 